Volume 1 Issue 1 Student Journal of Professional Practice and Academic Research

\title{
Pet Lamb and Clothed Hyena: Law as an Oppressive Force in Jane Eyre
}

\author{
Alexander Maine, Northumbria University PhD Candidate
}

\section{Introduction}

Writing in 1864, the literary critic Justin M'Carthy stated that 'the greatest social difficulty in England today is the relationship between men and women. ${ }^{11}$ This came at a time of unprecedented social and legal change of the status of women in the $19^{\text {th }}$ Century. A prominent novel of the time concerning such social difficulty is Charlotte Brontë's Jane Eyre: An Autobiography which attempts to reflect these social difficulties as often resulting from law. As such, the novel may be used as a reflection of the condition of nineteenth century English law as an oppressive force against women. This force is one that enacts morality through legality, and has particular resonance in literature concerning social issues. Jane Eyre will be discussed as a novel that provides insights into women's experiences in the mid-nineteenth century. Law is represented within the novel as an oppressive force that directly subjugates women, and as such the novel may be regarded as an early liberal feminist work that challenges the condition of law. This article will explore the link between good moral behaviour, and moral madness, the latter being perceived as a threat to the domestic and the law's response to this threat. It will pick upon certain themes presented by Brontë, such as injustice towards women, wrongful confinement, insanity and adulterous immoral behaviour, to come to the conclusion that the novelist presented law as a method of constructing immorality and injustice, representing inequality and repression.

Brontë's novel Jane Eyre: An Autobiography, a bildungsroman and written in the testamentary style, is a leading $19^{\text {th }}$ century example of literature concerning societal anxieties, women's position in Victorian society and the implications of the condition of law. Brontë uses Jane Eyre as a narrator with a self-identified perspective of a 'rebel slave' ${ }^{2}$ in order to construct a character inherently critical of the patriarchal societal structures which continuously hinder her struggle for independence. ${ }^{3}$ The novel seeks to demonstrate and lament the injustices perpetuated by law,

\footnotetext{
${ }^{1}$ J M’Carthy, 'Novels with a Purpose’ (1864) 26(1) Westminster Review 24, 27.

${ }^{2}$ C Brontë, Jane Eyre: An Autobiography (9th Edn, London: Chatto \& Windus, 1972), 6

${ }^{3}$ H Glen, Charlotte Brontë: The Imagination in History, (Oxford University Press, 2002) 25
} 
notably in regard the inequality of women in marriage and the treatment of insanity. Jane may be interpreted as a evangelical liberal feminist (to modern audiences) who wishes for domestic equality. Her antithesis in the novel, Bertha Mason, is hidden away and presented as animalistic, as she transgresses the traditional notion of the wife. Mason is used to show the extent to which the law and society at the time rejected the mad, while implicitly criticising the restrictive structure of marriage. Therefore the novel concerns itself with the lack of equality in the condition of English law and the construction of marriage, reflecting a social and religious desire to conform. The conformist attitude of the protagonist shows the inexorable link in nineteenth century attitudes between the healthy ideal family and good moral behaviour.

\section{Rebel Slave}

Heralded as a literary forerunner of female empowerment, Brontë represents Jane Eyre as a bold, independently minded character whose is treated as an equal by her husband, and thus represents the author's political view on the treatment of women. We may interpret Brontë as taking what Eagleton has dubbed the 'Anglo-American' stance of feminist writing which seeks to position the woman in the public arena ${ }^{4}$ as a reliable narrator. This can be then used to assess the credibility of the novelist reflecting the condition of the law. As a female novelist, Brontë sought to place her characters in positions which allowed her to observe society, in order to reflect the way in which women were treated in the $19^{\text {th }}$ century. Jane states that:

"Nobody knows how many rebellions besides political rebellions ferment in the masses of life which people the earth [...] [women] suffer from too rigid a restraint, too absolute a stagnation, precisely as men would suffer; it is narrow-minded in their more privileged fellow creatures to say that they ought to confine themselves.”5

This statement alludes to the notion of rebellion against the patriarchal nature of society, whilst noting the fact that men and women may suffer similar injustices, yet women bear the brunt and are destined to suffer theirs unless there is substantial social change, in keeping with her status as a rebel slave. As we will see, Jane and Bertha come to represent two radically different approaches to this rebellion. The notion of a fermenting rebellion offers images of resentment boiling within

${ }^{4}$ M Eagleton, Feminist Literary Criticism (London: Longman, 1991) 1-21

${ }^{5}$ C Brontë, Jane Eyre: An Autobiography (9th Edn, London: Chatto \& Windus, 1972), 105 
the minds of many, particularly prominent in those women who are confined within their gender role. This notion perpetuates the theme of wrongful confinement which echoes throughout the novel, through the protagonist's firsthand experiences and that of Bertha's. Jane is literally confined in the 'red room' of Gateshead Hall by her aunt after the death of her parents, and her isolation within Thornfield as a governess serves to represent her as a woman confined by her maternal profession and her transgression of the behaviour expected of a young girl. Her engagement to Rochester presents a social and legal transgression as he is already married, subsuming the importance of family as defined by the sacred marriage. Acts such as Hardwicke's 1753 Marriage Act sought to uphold this principle by the prevention of clandestine, immoral marriages, and bastardy. ${ }^{6}$ This statute aimed to rectify the ailing marital system and its prevailing proscriptive legislative attitudes are also evident in the Marriage Act 1822. It is from this that we may examine the social backlash against the immorality presented in the novel.

Famed as of 'horrid taste’, as it was described by Brontë's contemporary writer Elizabeth Rigby, Jane Eyre 'is a proof how deeply the love for illegitimate romance is implanted in our nature' ${ }^{7}$, as the novelist plays to the vices and taboos of society. Jane initially objects to Rochester's proposal as she believes he is engaged to Miss Ingram, in order to preserve Jane’s standing as an impartial moral character: "for that fate you have already made your choice, and must abide by it". 8 The use of 'fate' represents notions of destiny and the sacred element of marriage, a rule which must be abided by, but is flouted by Rochester because of his first wife's transgression of her own sexuality. Jane states that his bride stands between them, yet Rochester refutes this as Jane would be his equal and likeness, contrasting the equality between them and the savagery of Bertha in his eyes.

\section{Pet Lamb}

Brontë uses pathetic fallacy as a representation of natural law in order to contrast the legal system, and natural divinity. Rochester states that he will be judged by God as a storm begins; Rochester explicitly stating his belief in divine judgement as a storm begins, as an immediate natural reaction

\footnotetext{
${ }^{6}$ D Lemmings, Marriage and the law in the eighteenth century: Hardwicke's Marriage Act of 1753 (Cambridge 1996) The Historical Journal, 39, 339-360

${ }^{7}$ E Rigby, Vanity Fair and Jane Eyre (1849, Quarterly Review)

${ }^{8}$ C Brontë, Jane Eyre: An Autobiography (9th Edn, London: Chatto \& Windus, 1972), 250
} 
against his moral turpitude, with a lightning strike representing divine wrath over Thornfield. This reinforces the principle Bunyanesque theme of holy judgement taking precedence over legal manmade constructions, demonstrating a critical view of the condition of law which affords so much power to mere men. This consideration of natural law demonstrates Brontë's representation of the condition of law as inherently moralistic.

The principle of coverture ${ }^{9}$ demonstrates how marriage was an instrument for confining and regulating female sexuality and legal autonomy; coverture would strip the woman of all legal rights and ownership, as she became her husband's property. Rochester alludes to this principle as he calls her his "pet lamb” 10 which not only carries gendered masculine/feminine connotations but implies ownership of Jane far before they had even married, providing a critique of the ways women were transferred from one household to another. This is reflected in the confinement of Mrs Fairfax and Adele, yet contrasting the physical confinement of the wildly animalistic Bertha. The attempt of the law to proscribe marriage meant the reinforcing of Christian ideals, severely imposing gendered roles on women. Jane Eyre may be seen as a rejection and criticism of this, with the effects of family and marriage laws, particularly the culture of the private family being one of the driving forces behind social anxiety and personal hardship within the novel.

Drawing on the conflict between perceptions of manmade law and divine law, Jane states: “The human and fallible should not arrogate a power with which the divine and perfect alone can be safely entrusted"11. This may be read as a critique of the law and its nature as it unjustifiably takes away from God and enforces the will of the ruling classes. This critique is notably gendered and class-based as lawmakers are historically wealthy and male, embodied in Jane's statement that Rochester is "human and fallible" 12 , emblematic of the problem of man-made law. Despite his family having fallen from grace; he himself seeks to make his own law. We see this critique imposed on marital law, and may read her abrogation of the subjective moral tendencies of the law as facilitating ill-conceived forms of justice within the novel. This allows characters such as Lord Ingram to act within their own perceived judicial capacity:

\footnotetext{
${ }^{9}$ K O’Donovan, Family Law Matters (Pluto, 1993) 59

${ }^{10}$ C Brontë, Jane Eyre: An Autobiography (9th Edn, London: Chatto \& Windus, 1972), 211

${ }^{11}$ Ibid., p. 134

12 Ibid., p. 134
} 
"I helped you in prosecuting (or persecuting) your tutor, whey-faced Mr. Vining [...] He and Miss Wilson took the liberty of falling in love with each other [...] which we interpreted as tokens of 'la belle passion' and I promise you the public soon had the benefit of our discovery; we employed it as a sort of lever to hoist our dead-weights from the house. Dear mama, there, as soon as she got an inkling of the business, found out that it was of an immoral tendency."13

Here we see a member of the aristocracy taking it to be his duty to protect the public from the moral crime of pre-marital sex. Taking the liberty of falling in love and committing sexual intercourse to then be expelled from the house shows the law's function in preserving not only moral standards but the integrity of unmarried women in order to make their marriage profitable. From this, a public/private distinction is fostered and applied to the central themes of family, moral madness and lunacy: sexual immorality between the two partners was deemed to be public knowledge, yet lunacy, that is to say moral madness, often a highly gendered and discriminatory 'crime', was hidden away, as was the case of Bertha Mason. Here we see the hypocrisy that perpetuates Brontë's view of the English condition of law and its fostered hierarchy, evident in the Ingram's and Mr Brocklehurst. Brocklehurst's postulation that his school should "render [girls] hardy, patient, self-denying”" 14 is key to understanding perceptions of women and female sexuality of the time, yet Brocklehurst did not treat his own daughters that way. We may also see that Bertha is in fact denied so much human interaction that she turns feral. From this, the implications of marital law, particularly those that kept the woman desexualised within the home, show the condition of the English law to be inherently misogynistic and patriarchal.

\section{Clothed Hyena}

Bertha Mason, Rochester's hidden away wife, is the iconic and disturbing antithesis of Victorian moral norms. Bertha is a rampantly aggressive sexual character, capable of destroying the 'domestic' quiet of Thornfield, which, as argued by Armstrong, is used by Brontë to critique the fragility of the Victorian domestic ideal. ${ }^{15}$ It is from this critique that we see the importance of noting the imputations of 'moral madness' in English law. Throughout, Bertha is demonised as the

\footnotetext{
${ }^{13}$ Ibid., p. 173

${ }^{14}$ C Brontë, Jane Eyre: An Autobiography (9th Edn, London: Chatto \& Windus, 1972), 57

${ }^{15}$ N Armstrong, Desire and Domestic Fiction: A Political History of the Novel (Oxford University Press, 1987) 164 
antithesis of Jane; Jane is a lamb, while Bertha is a savage "clothed hyena”. Jane foreshadows the theme of the madness within the novel, while implying that madness may arise through the social construction of the desexualised woman:

"it is madness in all women to let a secret love kindle within them, which, if unreturned and unknown, must devour the life that feeds it; and, if discovered and responded to, must lead, ignis-fatuus-like, into miry wilds whence there is no extrication.”16

Jane's collective assertion of all women is typical of her conformist ideals, however this statement foreshadows the destruction of Thornfield as Bertha burns it down and fire devours the house, while Jane leaves and wanders the wilds as an outcast. Brontë uses Bertha as an obvious symbol of destruction and madness, yet she has become this way because of the way society has treated her and how her marriage has imprisoned her. The most prevalent solution to the madness of a family member at the time was to hide them away in order to save family reputation and avoid the Lunacy Commission. The Commission developed as a means of committing the mad, and protecting moral values, yet was self-fashioned and had little legitimacy or regulation. The culture regarding lunacy and madness may therefore have been founded in this uncertainty in the law and a lack of justice for those deemed to be mad. Loss of autonomy and misrepresentation are key to the anxiety over the commission and the ease with which someone could be committed, as a judicator was not required to observe the subject beforehand and the law provided little in the way of protection for the individuals. This shows the fear of misrepresentation in the Victorian society, as respectability and profitability were of the utmost importance, being particularly noticeable in the 1802 case of Ridgway $v$ Darwin ${ }^{17}$ in which the ability to manage an estate and therefore benefit one's family was deemed to be the standard of a sound mind. ${ }^{18}$ The increased interest in madness and the emergence of psychiatry led to a tension between lawyers and medics of who was best suited to commit an insane person, indicative of the unsure place of law and its presumption of dominance. The domestic imprisonment of Bertha is used to represent the enforcement of gendered preconceptions, Bertha may have been undomesticated, yet she was still maintained within the confines of her marital home.

\footnotetext{
${ }^{16}$ C Brontë, Jane Eyre: An Autobiography (9th Edn, London: Chatto \& Windus, 1972), 156

${ }^{17}$ Ridgway v Darwin [1802] 32 ER 164

${ }^{18}$ I Ward, Law and the Brontës (Palgrave Macmillan, 2011) 75
} 
The representations of madness within the novel, however, do not take a legal or medical basis, yet depend on the strongly evangelical moralism perceived by Jane and by Rochester's disgust. Bertha comes to typify many of the fears of the Victorians: a fear of sexual women, the wrongfully confined, and the foreign; a West Indian woman, married to a wealthy English aristocrat. Her marriage into the aristocracy is indicative of changing society and social mobility, something which the guests of Thornfield fear, while the theme of slavery resonates in the prevalence of racially inflected images of submission. ${ }^{19}$ Racial themes may be developed in order to understand Bertha's madness; the 'germs of insanity' ${ }^{20}$ are inherited from her Creole mother, a reference which may give understanding to Bertha as 'the racial Other incarnate' ${ }^{21}$ : her status as mixed-race emerges as not just black or white, but a form of familiar fraternising with the unfamiliar. Rochester recalls her as “coarse and trite, perverse and imbecile”, using this paradoxical discourse to impart madness ${ }^{22}$ that is cunning and yet unresponsive and in complete contrast to the plain and evangelical Jane. Therefore her morality is plainly opposed and foreign to English morality, on which common law rests. Not only is she the antithesis of the model Victorian wife, she is related to the hyena, the biblical devourer of corpses and representative of gender disturbances: 'The ancients said that the hyena is able to change its sex, and used it as a symbol of the unstable man' ${ }^{23}$. This clearly resonates with Bertha's unfeminine character, whilst the unstable man reflects Rochester as the bigamous, unholy man. This may be read as Brontë's attempt to underpin the centrality and significance of a valid and moral marriage and the importance of the relationship between man and woman.

Bertha's madness is not just representative of her own immorality, but a parallel of Rochester's abusive character, exhibited by the "virile force" of her insanity contrasting "the uncontainable violence of his desires, and its implications'. ${ }^{24}$ This virility again reinforces the parallels drawn between Jane and Bertha and also contrasts the virginity of Jane and her distrust of sexual behaviour. The violence within Rochester is consolidated and serves to emphasise the lack of legal protection afforded to abused women when the symbolic slave/master lexicon is re-examined. The

\footnotetext{
${ }^{19}$ I Ward, Law and the Brontës (Palgrave Macmillan, 2011) 90

${ }^{20}$ C Brontë, Jane Eyre: An Autobiography (9th Edn, London: Chatto \& Windus, 1972), 304

${ }^{21}$ S Perera, Reaches of Empire: The English Novel from Edgeworth to Dickens (New York: Columbia UP, 1991$) 82$

22 S Thomas, 'The Tropical Extravagance of Bertha Mason' (1999) Victorian Literature and Culture Vol 27, 6

${ }^{23}$ F Webber, Church Symbolism: An Explanation of the More Important Symbols of the Old and New Testament, the Primitive, the Medieval and the Modern Church (2nd ed. 1938. Detroit: Gale, 1971)

${ }^{24}$ S Thomas, 'The Tropical Extravagance of Bertha Mason’ (1999) Victorian Literature and Culture Vol 27, 11
} 
theme of constraint; physical, emotional and gendered, dominates Jane Eyre. ${ }^{25}$ The comparisons of Jane to the concubines of seraglios in the East serve to mirror Thornfield and its inmates, 'all enduring different forms of confinement and alienation'. ${ }^{26}$ This subjugation is emphasised when Rochester attempts to buy her clothes after their engagement and she abhors his despotism and demanding behaviour. The language used throughout the chapter when referring to Rochester is dangerous and intimidating as she recoils against his touch and his 'falcon eye', though despite this, she is attracted to his 'imperial masculinity' ${ }^{27}$ and proceeds to idolise him as she "could not in those days, see God for His creature, of whom I had made an idol"28. This clearly represents Jane's descent into moral turpitude ${ }^{29}$ as she is engaged and may then be interpreted to reflect Brontë's thoughts on the condition of English law; lacking fundamental adherence to divine law. This in turn reflects divorce and the difficulty in obtaining one, with the fate of the inescapable marriage acting as a representation of unjust law. The Matrimonial Causes Act 1857 allowed divorce under the terms of 'cruelty', yet mere spousal abuse did not amount to such. The act 'reinscribed both class and sexual double standards, and its passage effectively foreclosed substantive action on these inequities until the 1880s. ${ }^{30}$ Therefore we see Brontë's use of pejorative language throughout the course of Jane's proposal as a means to comment on the nature of legal marriage and the gender struggles within. However, as Poovey notes, the unfair terms of marriage remained unchanged until the 1880s: Brontë's writings may have been incredibly influential and still resonates within today's society, yet they did not bring around revolutionary legal change that would assist the plight of women, something which Jane Eyre aspires to. Jane presents herself as a missionary, sent to assist the women in the seraglios, yet through liberal feminist ideals, she predominantly focuses on the bettering of her own life, rather than attempting to bring significant change for others.

\footnotetext{
${ }^{25}$ S Shuttleworth, Charlotte Brontë and Modern Psychology (Cambridge University Press, 1996) 148

${ }^{26}$ I Ward, Law and the Brontës (Palgrave Macmillan, 2011) 86

${ }^{27}$ S Thomas, ‘The Tropical Extravagance of Bertha Mason’ (1999) Victorian Literature and Culture Vol 27, 6

${ }^{28}$ C Brontë, Jane Eyre: An Autobiography (9th Edn, London: Chatto \& Windus, 1972), 271

${ }^{29}$ M Williams, Secrets and Laws (London: University College London Press) 116

${ }^{30}$ M Poovey, Covered but not bound: Caroline Norton and the 1857 Matrimonial Causes Act (1988 Vol 14 Feminist Studies) 468
} 


\section{Conclusion}

It is important to consider Brontë's most telling representation of her own perceived condition of the law, through Jane as the narrator. Rochester asks whether to be driven to despair is better than the transgression of a 'mere human law'. Jane responds:

"I will keep the law given by God; sanctioned by man.”"

This constructs the clear distinction in Jane Eyre between law and justice, in order to provide a vision of Victorian English law that manipulates Christian morality and therefore is lacking in divine justice. This is primarily presented through the perspective of a woman's struggle and therefore allows for the presentation of Jane Eyre as a feminist novel through the continual tension between genders from the injustices fostered through law's manipulation. This tension can then be used to show how the nineteenth century novel is utilised by the novelist in order to present distaste and dissatisfaction with the condition of English law as it stood, failing to preserve Christian morals and allowing for the abuse of women by men and the masculine construction of law.

${ }^{31}$ C Brontë, Jane Eyre: An Autobiography (9th Edn, London: Chatto \& Windus, 1972), 315 